\title{
PRODUCTION AND CONSUMPTION OF SCIENCE IN A GLOBAL CONTEXT
}

Historically, Brazilian nurses have been highly influenced by their American counterparts as to what constitutes and how to practise scientific nursing care. This relationship started in the early 1920 s, when the Rockefeller Foundation sent American nurses to Brazil (as well as to other countries) to help Brazilians establish nursing higher education. These US nurses were sent to Rio de Janeiro, a port exporting Brazilian products for the American and European markets, to promote higher standards of public health ${ }^{(1,2)}$.

Despite the passage of 80 years, the principle of this rela-tionship remains the same, even though it has been affected by the current globalization movement. Presently, English-speaking nurses publish work that sets standards and guide-lines for our development. This pattern still prevails despite the fact that Brazilian nurses have been able to rely on two dozen Brazilian nursing scientific journals, nine PhD pro-grams (over 20 years of doctoral education), and 21 Master's programs (over 30 years of master's education) attended by nurses from many Latin American countries.

So far, the dominance of the scientific model of American nursing has prevented fruitful exchanges between Brazilian (Portuguese-speaking) and English-speaking nurses. In this model, which mirrors the commercial relationships between first world countries and third world countries, English-speaking nurses are producers of knowledge, while non-English speaking nurses are its supposed consumers ${ }^{(3)}$. When Brazilian, Portuguese-speaking nurses try to resist this dominant model and establish equal relationships, a seriesof subtle but effective barriers comes into play.

The foremost barrier is the dominance of English in the scientific world. Although Brazilian nurses are expected to have mastery in a second language in order to qualify for a Master's degree (and a third language to attend a PhD program), Australian, New Zealander, British, Canadian, or American nurses have no requirements to demonstrate foreign language skills to undertake doctoral education. Many times, language skills are not even considered in the selection process. The result of this policy, given the inability of most English-speaking nurses to read any other language, is that the only dissemination strategy available to nonEnglish-speaking nurses to move beyond the passive role of consumer is to publish in English. This sole alternative carries with it a series of consequences in terms of career trajectory and research funding for non-English-speaking nurses.

In order to foster an international knowledge producer's role for Brazilian nurses, nursing academia adopted 'international'standards. This means that it is almost compulsory for academics to publish in international journals if they want to progress in their careers or compete for research funding. Even though some top international journals are based in Brazil and Ibero-America and are published in Portuguese or Spanish, most international journals are published in English. When trying to achieve the goal of publishing in international journals, Brazilian researchers experience multiple forms of resistance from journals published in English. First, these English language journals seldom contemplate truly international issues, such as how to nurse in middle- and low-income countries, in their choice of themes or editorial approaches. In other words, what academics would consider international journals are all too often in reality regional journals (addressing high-income country issues) for English speakers.

A second element that reinforces our consumer role is the expectation of many journals published in Englishspeaking countries that references be published in English and be accessible to the English-speaking international audience. This means that those journals published in highincome countries by powerful publishing houses ensure the wide dissemination of their works. This is a barrier too because cost prohibits access of many Brazilian researchers to a full range of English-language journals. Finally, there is a limit to the number of 'international' articles one can reference when writing about a Brazilian issue.

Furthermore, authors who write English as a second language are offered very little support to get their manuscripts published. Reviewers frequently do not suggest alternatives to language or content problems they encounter in the article or their comments disregard the cultural context in which the paper was produced. Editors expect identical language proficiency from all authors. In part, this problem reflects the small number of international reviewers on some journals. Appointing a few members who speak English as second language, from low- or middle-income countries, to the editorial board is a solution some journals have adopted, but in many cases this is merely cosmetic.

Paradoxically, our collective awareness of these international exclusionary mechanisms does not prevent similardiscriminatory practices from operating inside Brazil. Due, in part, to our continental territorial dimension and the dis-parity in regional development, some groups with the same nationality share greater benefits while others experience greater hardship with regard to producing knowledge. This phenomenon produces internal levels of exclusion that are ignored by editors abroad and have not yet been tackled within the country. For instance, the Brazilian funding agency $\mathrm{CNPq}$ has awarded permanent salary incentives to nurse-researchers, $80 \%$ of whom are located in the states of São Paulo and Rio de Janeiro, and we have 24 other states in the country(4). Therefore, nurses from most other states face a double sort of exclusion: they have to fight against becoming mere consumers of knowledge produced both in English-speaking countries and in Brazil's south-eastern states.

In a Latin American context, Brazilian nursing has taken the lead with many initiatives. Perhaps we should say that Brazil, too, exercises relationships of dominance, like English-speaking countries do on the international scene. Even so, unlike the case of English-speaking countries, we are the only country in Latin America in which Portuguese is spoken. Consequently, we are the ones who use Spanish as 
a second language in order to communicate with other Latin Americans.

In trying to avoid reproducing the asymmetrical power relations we experience internationally and placing others in the role we do not want for ourselves, we have taken some initiatives that we believe move us toward greater scientific equity. So far, Brazilian nursing journals' editorial boards have undertaken two kinds of activities: (a) to work in mul-tiple languages within Brazilian nursing journals; and (b) to engage in capacity building to achieve common and quality-based standards for nursing journals in Brazil, Latin America, and Ibero-America.

The first step was to have all papers published in all Brazilian nursing journals include abstracts in three languages (Portuguese, Spanish, and English). Next, some of the most prestigious journals, for instance, Revista Brasileira de Enfermagem (www.abennacional.org.br) and Revista LatinoAmericana de Enfermagem (www.eerp.usp.br/rlaenf), began to regularly publish full papers in English or Spanish. To oppose - and break down - the necessity of being Englishspeaking to access scientific knowledge (a barrier to evidencebased practice for millions of nurses worldwide), a new journal, which publishes exclusively in Spanish, has recently been created (Revista Panamericana de Enfermería www.feppen.org) in Brazil, the current host country for the Nursing Profes-sionals'Pan-American Federation (FEPPEN) $)^{(5)}$. The journal's goal is to disseminate knowledge produced by Latin American nurses, in order to strengthen and promote a collective body of knowledge for countries in this region.

In terms of capacity building, Brazilian editors have been consolidating a national strategy by meeting regularly to standardize norms, discuss current challenges, and adapt the journals' styles to obtain international indexation ${ }^{(6)}$. At the international level, the Ibero-American Council of Editors of Nursing Journals was created in November 2003. Editors will meet bi-annually to promote strategies to position Spanish, Portuguese, and Latin American nurses as knowledge producers for their own region ${ }^{(5)}$.

Many Brazilian researchers experience being excluded from participating in the international/English-speaking scientific world and being limited to the role of consumer of English-speaking journals. Yet, the drastic disparities within Brazil also place other researchers in a comparable position at the national level, where instead of language, barriers involving access to resources and education exclude many nurse-researchers from a knowledge producer role. We believe that some of the initiatives of Latin American researchers and editorial boards could be used to inspire the English-speaking world, where monolingual scholarship creates exclusion by enabling some to become producers of global knowledge while relegating others to being mere consumers.

\section{References}

1. Sauthier j, Bareeira IA. As enfermeiras norte-americanas e o ensino de Enfermagem na capital do Brasil: 1921-1931. Rio de Janeiro: Universidade Federal do Rio de JANEIRO;1999.

2. Paiva MS. Enfermagem brasileira: contribuição da ABEn. Brasília (DF);1999.

3. Gastaldo,D. Caring nursing: politics from the South. Nursing Inquiry 2000 March;7(1)61-71.

4. Mendes IAC, Leite JL, Santos RM, Trevizan MA. Classificação dos pesquisadores/ consultores da área de enfermagem no CNPq: contribuição para um banco de dados. Revista Brasileira de Enfermagem, Brasília (DF) 2003 set/out;56(5):485-90.

5. Mancia JR. Para além das fronteiras: movimento dos editores. Revista Brasileira de Enfermagem, Brasília (DF) 2003 SET/OUT;56(5):473-4.

6. Mancia JR. Comissão editorial CAPES/AABEn: ação coletiva para qualificação dos periódicos de enfermagem. Revista Brasileira de Enfermagem, Brasília (DF) 2002 jul/ago;55(4):361-2. 